\title{
Lung nematodes of sheep (Ovis aries) in Iceland - prevalence, intensity and geographic distribution in 1992 and 1993
}

\author{
Hrafnkatla Eiríksdóttir And Karl Skírnisson \\ Institute for Experimental Pathology at Keldur, University of Iceland, Keldnavegur 3, IS-112, Reykjavik, Iceland \\ E-mail:hrafnkatla.eiriks@gmail.com,karlsk@hi.is
}

\begin{abstract}
During the slaughter period in autumn 1992 and 1993 lungs and the gastrointestinal tract was collected from a single lamb originating from 96 sheep farms, selected to reflect the distribution of farms in Iceland. The results on the gastrointestinal helminths have already been published. The lungs were kept frozen until analysed in 2019. Nematodes were directly searched for in the lungs of 84 lambs. Results on larval counts were handed over to the present authors for comparison purposes.

Three lungworm nematode species were detected: Muellerius capillaris (total prevalence 35.1\%), Protostrongylus sp. (2.4\%), and Dictyocaulus filaria (16.7\%). M. capillaris was found in lambs from all parts of Iceland except from certain areas in the north and northeast. Protostrogylus sp. was detected on two adjacent farms in the north. D. filaria was frequently found in lambs from farms in the southern and western parts, whereas sporadic cases were found in north and east Iceland. As relatively few lambs were examined, the distribution area of sheep lungworm in the early 1990s is regarded to have been more extensive than indicated in the article.
\end{abstract}

Keywords: Lung nematodes, Iceland, Muellerius capillaris, Protostrongylus sp., Dictyocaulus filaria.

\section{YFIRLIT}

Lungnaormar i sauðfé (Ovis aries) á Íslandi - smittiðni, smitmagn og útbreiðslan 1992-1993

Á sláturtíðinni 1992 og 1993 var lungum og meltingarvegi safnað úr 96 lömbum, einu lambi frá hverjum bæ. Bæirnir voru valdir með pað í huga að endurspegla dreifingu sauðfjárbýla á Íslandi. Niðurstöður rannsókna á iðraormum hafa pegar verið birtar en hér er gerð grein fyrir rannsóknum á lungnaormum. Lungu voru varðveitt í frosti fram til ársins 2019 pegar lungnaormasmit í peim var rannsakað. Höfundar fengu aðgang að lirfutalningum og tegundagreiningum í saur lambanna (Sigurður H. Richter, óbirt gögn).

Prjár tegundir lungnapráðorma fundust í rannsókninni: lungnaörðuormurinn Muellerius capillaris (heildarsmittíðni 35,1\%), litli barkapípuormurinn Protostrongylus sp. (2,4\%) og stóri barkapípuormurinn D. filaria $(16,7 \%)$. Lungnaörðuormurinn fannst í lömbum um allt land nema á norður- og norðausturlandi. Litli barkapípuormurinn fannst einvörðungu á tveimur bæjum í Eyjafirði. Stóri barkarpípuormurinn fannst í öllum landshlutum en var algengastur sunnan og vestanlands. Vegna pess hversu fá sýni voru skoðuð gefa útbreiðslukort í greininni til kynna lágmarksútbreiðslu viðkomandi tegunda.

\section{INTRODUCTION}

Parasitic nematodes of the order Strongylida infect the respiratory tract of ruminants and often cause bronchitis or pneumonia (Taylor et al. 2007). Lung nematodes are commonly found in sheep and are divided into small lungworms (protostrongylids) and large lungworms 
(dictyocaulids). They are economically important by causing production losses and contributing to increased host mortality (Soulsby 1965, Pandey et al. 1984, Belay \& Mengsha 2016, Deplazes et al. 2016). For development the protostrongylids require a terrestrial gastropod as intermediate host, making their distribution dependent on the geographical spread of the snail host (Robb \& Samuel 1990, Georgiev \& Georgiev 2002, Jenkins et al. 2006). Dictyocaulids, however, have a direct life cycle, where first-stage larvae (L1) are shed by the host in the faeces. Maturation to the infective third-stage larvae (L3) occurs in the environment where they are ingested by the host via grazing (Soulsby 1965).

In Iceland, sheep products are an important food source that contributed to over $50 \%$ of the total annual meat production in the country in 1992 and 1993 (Statistics Iceland 2020). In the 1930s, Iceland was divided into quarantine zones to hinder the spread of sheep diseases that were introduced to the country in 1933 with imported karakul sheep (Sigurðsson 1954). At the present time, these zones have increased in number. Transportation of sheep between these areas is prohibited, except from designated clean zones with special permission (Act No. 25/1993 on animal diseases and controlling measures). Therefore, it is proposed that the parasite species composition varies within the island.

In Iceland, pioneer studies on lungworm infections in sheep were carried out in the 1960s and the 1970s. The studies were mainly performed in the west and south-west parts of Iceland, reporting the presence of both Muellerius capillaris and Dictyocaulus filaria (Gíslason 1965, Richter 1974, Richter 1976, Richter 1979, Richter et al. 1983). Earlier, Einarsson (1936) had reported the presence of Protostrongylus rufescens in lungs of sheep in East Iceland.

In the early 1990s, an extensive survey was carried out at the Institute for Experimental Pathology at Keldur with the aim to identify helminth parasites of sheep in Iceland and examine their prevalence, abundance and geographic distribution. For this purpose, gastrointestinal and respiratory organs were collected during the slaughter period (September and October) in 1992 and 1993. Samples were collected from one lamb from each of the 96 distinct Icelandic sheep farms that had been selected to reflect the distribution of sheep farms in the country. The studies on the gastrointestinal helminths were completed and subsequently published (Richter 2002). In connection with these studies a faecal sample from each lamb was also examined for the presence of parasites, including identifications and counts of lung nematode larvae (Sigurður H. Richter, unpublished data). However, the lungs were not examined until 2019. The aim of this article is to present the nematode infections detected in the lungs and in the faeces of these lambs and give an overview of their occurrence and geographic distribution in Iceland in the early 1990s.

\section{MATERIALS AND METHODS}

Study animals, and sampling: The study covered 96 sheep farms all around Iceland. The gastrointestinal tract, lungs or a faecal sample were collected in abattoirs by assigned veterinarians in September and October 1992 and 1993 from 96 healthy lambs, one from each sheep farm. For the present study, lungs together with a faecal sample were available from 82 lambs. A faecal sample without the lungs was available from 12 lambs, and lastly, lungs but no faecal sample were present from lambs from two farms (Figure 1). Immediately after slaughter the intestine and lung samples were put in separate plastic bags, labelled with the name of the farm and immediately frozen. Later, the frozen samples were sent to Keldur, where the material was kept frozen at $-20^{\circ} \mathrm{C}$ until analysis. The gastrointestinal organs and the faecal samples were examined 1-16 months after slaughter (Richter 2002).

Lung examination: The lungs $(\mathrm{n}=84)$ were dissected in late summer 2019 after having been kept frozen since 1992 or 1993. Before dissection, the lungs thawed overnight in the plastic bag at room temperature. The lungs were placed in a tray with c. $20 \mathrm{ml}$ of tap water and slightly inflated by pressing air into the trachea. The wet surface was macroscopically examined 


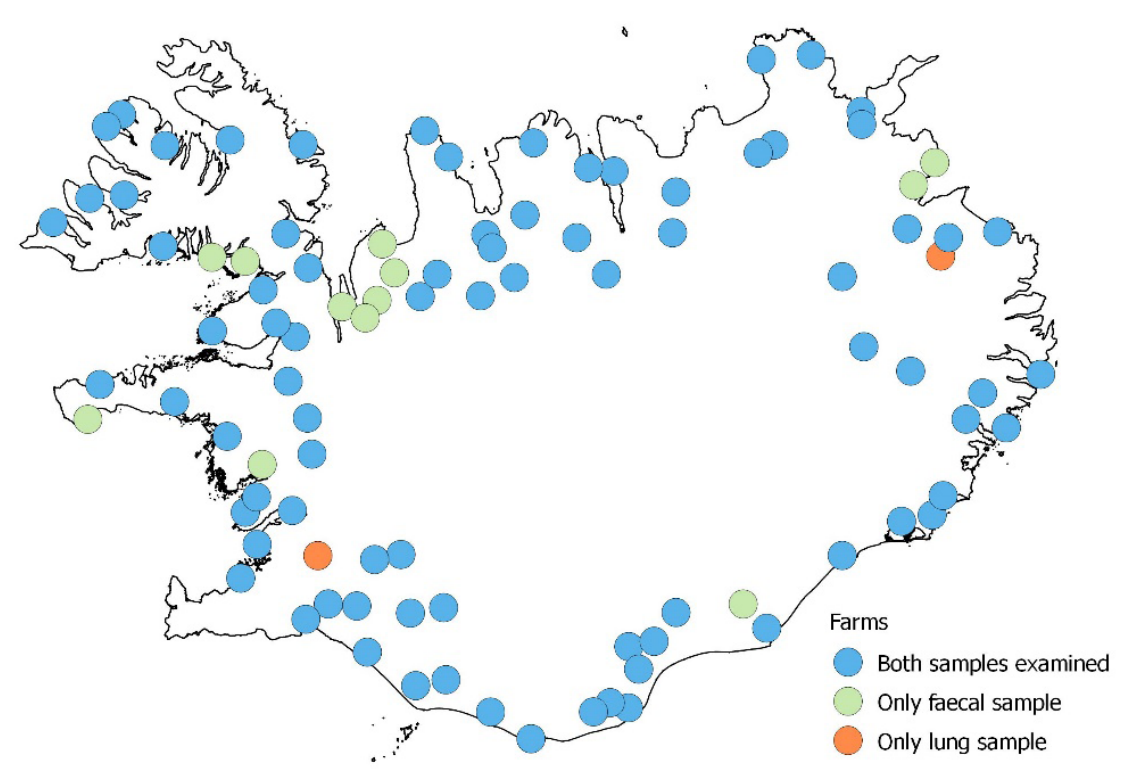

Figure 1. Distribution of 96 sheep farms in Iceland where lung and/or faecal samples of lambs were collected during autumn slaughtering period 1992-1993 to study lungworm nematode infections.

for lesions (worm nodules and brood nodes) related to lungworm infections (Mehlhorn 1988, Deplazes et al 2016) and subsequently photographed. For a lung to be positively identified as having worm nodules, at least one subpleural granular nodule $(1-3 \mathrm{~mm}$ in diameter) had to be present on the lung surface (see Figure 2) indicating the presence of a few dead and calcified worms, or represent live worms, located close to the surface.

Following the gross morphology examination, the trachea, bronchi, and bronchioles were cut open, visible lungworms collected, and tissue scrapings from the trachea and bronchi were taken and put on a microscope slide to examine for the presence of lungworm larvae. After cutting all bronchioles open, the lungs were washed three times in a 10-litre bucket, half-filled with tap water, and the fingers used to wipe off mucous and worms into the water. After each wash, the water and its contents were poured through a sieve of 250 $\mu \mathrm{m}$ mesh size. Finally, the material remaining in the sieve was transferred into a petri dish and examined for the presence of lungworm specimens under a dissection microscope. $D$. filaria and Protostrongylus sp. from each lamb were identified according to the morphological description given by Gerichter (1951) and Soulsby (1965) and counted and fixed in $70 \%$ ethanol. Adult M. capillaris worms are embedded in the lung tissue and cannot be detected with this method. However, in some of the lambs, great numbers of the small first-stage larvae (Figure 3) were noted to be entangled in mucosa clumps that did not pass through the sieve by washing the lungs. As such findings confirm the presence of $M$. capillaris, these cases were also evaluated (Table 2).

Faecal examination: Faecal samples were collected from the recta of 94 lambs. A modified Baermann technique, based on the description of Henriksen (1965), was used to extract lungworm larvae from three grams of faeces from each lamb. The larvae were identified to species according to morphological characteristics (Soulsby 1965, Ministry of Agriculture, Fisheries and Food 1986) and counted. Because faecal examination was done with frozen material, the negative effect on the 


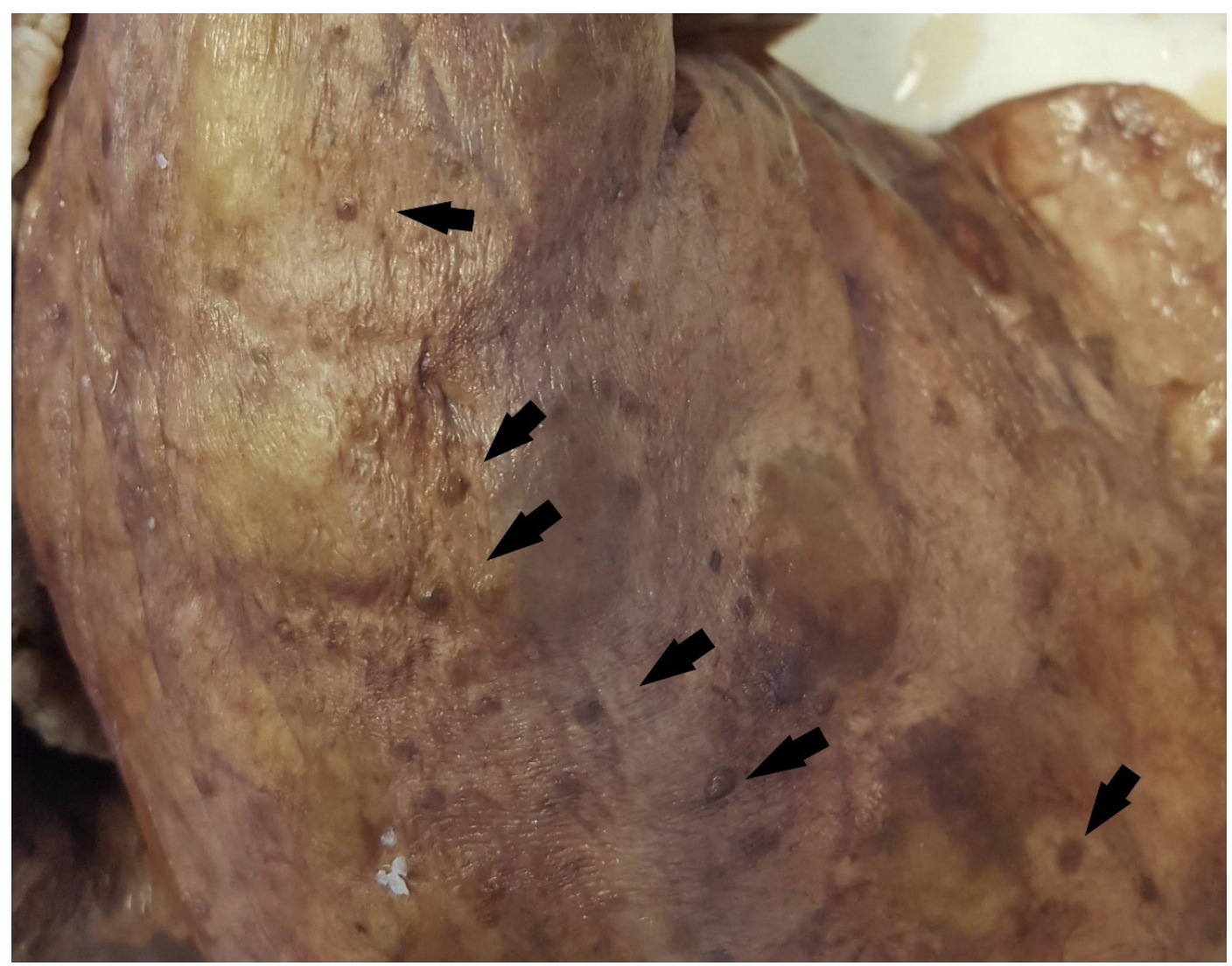

Figure 2. Lung of a lamb showing dark worm nodules on the lung surface (black arrows) caused by the lung nematode Muellerius capillaris. The lesions are irregularly spread over the surface. Further explanations in text.

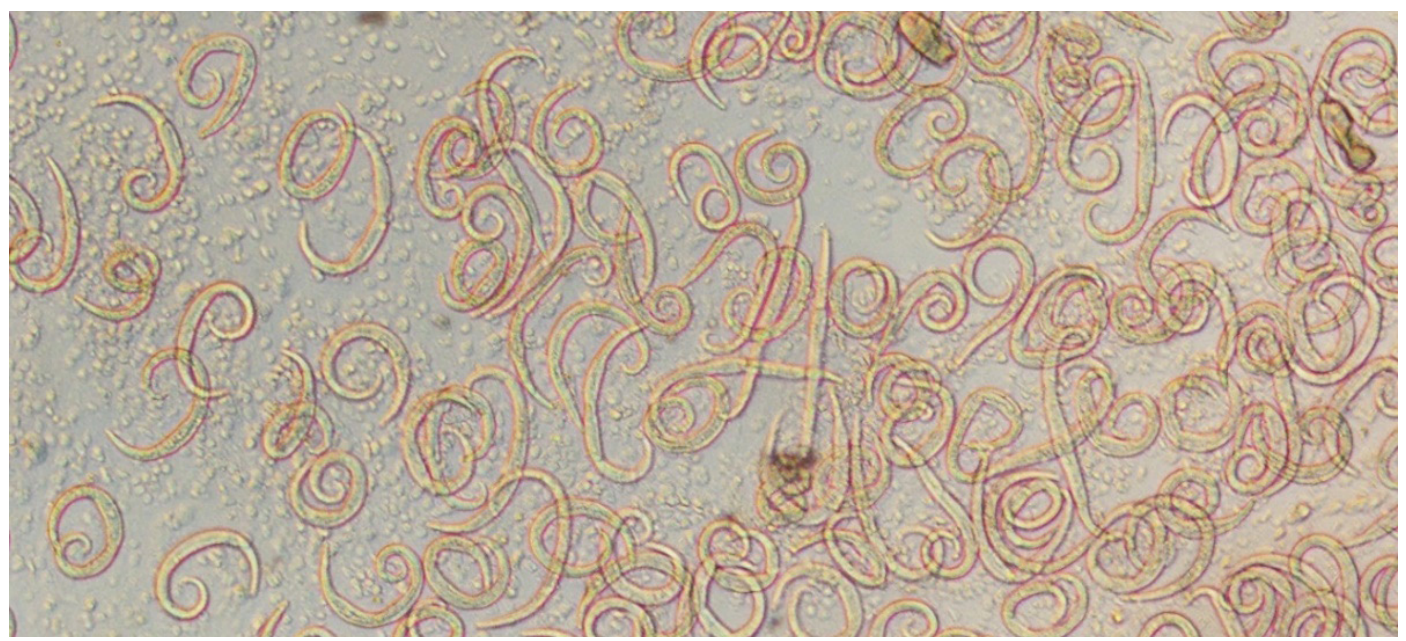

Figure 3. After cutting up the bronchial tree and subsequently washing the lungs into a sieve, sometimes huge numbers of Muellerius capillaris first-stage larvae, entangled in mucosa clumps, confirmed the infection by the nematode. The adults are located within the lung tissue and do not appear when the larger lungworm species are searched for in the bronchial tree. 
survival rates of lungworm larvae should be mentioned (Rose, 1955; Rose 1957).

This part of the study was carried out by Sigurður H. Richter and his co-workers during 1992 to 1994. The unpublished results (larvae per gram faeces) were handed over to the present authors to enable comparison with the results obtained with the direct lung examinations.

Molecular analysis: In order to identify nematode species involved in cases where only morphologically unidentifiable female worms were present in the lungs, or when the posterior end of the male nematode (necessary for the morphological analysis) was missing, the identity of these specimens (D. filaria or Protostrongylus sp.) was studied with molecular methods. DNA was extracted by using a QIAamp DNA kit (QIAGEN) in the QiacubeHT, tissue program.

The primers used for the PCR amplification are generally used to mark the ITS-2 region of nematode species and were previously described by Gasser et al. (1993) (NC1: 5 '-ACGTCTGGTTCAGGGTTGTT-3', NC2: 5 '-TTAGTTTCTTTTCCTCCGCT-3').

PCR assay was performed with a total volume of $25 \mu \mathrm{l}$ which consisted of: $12.5 \mu \mathrm{l}$ TAQ2X Master mix (New England BioLabs), $0.25 \mu \mathrm{l}$ of each primer $(20 \mu \mathrm{M})$ and $3 \mu \mathrm{l}$ template DNA. After initial denaturation for $30 \mathrm{sec}$ at $95^{\circ} \mathrm{C}, 35$ cycles were carried out. Each cycle consisted of denaturing at $95^{\circ} \mathrm{C}$ for $45 \mathrm{sec}$, annealing temperature at $56^{\circ} \mathrm{C}$ for 30 seconds and extension at $68^{\circ} \mathrm{C}$ for $60 \mathrm{sec}$ with final extension at $68^{\circ} \mathrm{C}$ for five minutes. Further, samples were cleaned off and sent for sequencing.
Data analysis: Results were recorded into Microsoft Excel where all descriptive statistics were performed. The statistical program RStudio was used for statistical analysis. For geographical mapping and analysis, the GIS program QGIS was used.

\section{RESULTS}

Three lungworm nematode species were found in the study: two protostrongylids, $M$. capillaris and Protostrongylus sp., and the dictyocaulid $D$. filaria.

Faecal examination: Lungworm larvae were found in $35.1 \%$ of the faecal samples $(n=94)$ (Table 1). Faecal examinations never revealed mixed lungworm infections, and only two species were detected: $M$. capillaris and D. filaria.

Search for adult lungworms: Adult lungworms were detected in lungs from 20 lambs (23.8\%) (Table 2). Three lambs hosted a mixed infections of $M$. capillaris and D. filaria, and one lamb had a mixed infection of Protostrongylus sp. and D. filaria.

Locations of worm nodules on the lung surface were evaluated as belonging to $M$. capillaris. Worm nodules are well known indicators for Muellerius sp. or Cystocaulus sp. infections in lungs of ruminants (Mehlhorn 1988, Deplazes et al 2016). However, as Cystocaulus sp. has never been found in Iceland and was not recorded in faecal samples during this study, the presence of such worm nodules on the lung surface were taken as an indicator of an $M$. capillaris infection. Presence of brood nodes was noticed on the lung surface but could not be systematically evaluated as these lesions sometimes become indistinct in the frozen material.

Table 1. Prevalence of infection (with 95\% CI), average intensity and range of larval numbers per gram faeces (lpg values) of lungworm nematode species detected in faecal samples of 94 lambs sampled in autumn 1992 or 1993 in different parts of Iceland.

\begin{tabular}{lccccc}
\hline & $\begin{array}{c}\text { No. of } \\
\text { examined }\end{array}$ & $\begin{array}{c}\text { No. of } \\
\text { infected }\end{array}$ & $\begin{array}{c}\text { Prevalence (\%) } \\
(95 \% \mathrm{CI})\end{array}$ & $\begin{array}{c}\text { Average intensity } \\
(\mathrm{lpg}) \pm \text { SD }\end{array}$ & Range (lpg) \\
\hline Faecal examination & & & & & \\
Muellerius capillaris & 94 & 33 & $35.1(25.5-45.6)$ & $33 \pm 57$ & $1-246$ \\
Protostrongylus sp. & 94 & 0 & - & - & - \\
Dictyocaulus filaria & 94 & 1 & $1.1(0.0-5.8)$ & 2 & 2 \\
\hline
\end{tabular}


Table 2. Prevalence of infection, average intensity and range of adult Protostrongylus sp. and Dictyocaulus filaria worms, and larvae numbers per gram faeces (lpg values) of Muellerius capillaris detected in lungs of 84 lambs sampled in autumn 1992 or 1993 from sheep farms located in different parts of Iceland.

\begin{tabular}{lccccc}
\hline & $\begin{array}{c}\text { No. of } \\
\text { examined }\end{array}$ & $\begin{array}{c}\text { No. of } \\
\text { infected }\end{array}$ & $\begin{array}{c}\text { Prevalence (\%) } \\
(95 \% \mathrm{CI})\end{array}$ & $\begin{array}{c}\text { Average intensity } \\
(\mathrm{lpg}) \pm \text { SD }\end{array}$ & Range (lpg) \\
\hline Lung examination & & & & & \\
Muellerius capillaris* & 84 & 8 & $9.5(4.2-17.9)$ & - & $11-150+$ \\
Protostrongylus sp. & 84 & 2 & $2.4(0.3-8.3)$ & 1 & 1 \\
Dictyocaulus filaria & 84 & 14 & $16.7(9.4-26.4)$ & $3 \pm 4$ & $1-17$ \\
\hline
\end{tabular}

*Adult Muellerius capillaris worms were never recovered from the lungs. However, first stage larvae (L1) can occasionally be found in mucus clumps from lungs by using the washing method described in the text. Numbers exceeding 150 larvae per lamb were not counted.

\section{Muellerius capillaris}

Worm nodules were observed on the lung surface of $23.8 \%$ of the lambs examined in the survey. Up to 170 worm nodules were noticed on lungs of the most heavily infected lambs; on average 24 nodules ( \pm 39 SD) were counted. The nodules were recorded especially dorsocaudally on the lungs, with both focal and multifocal distribution observed especially in cases of heavier infections. No worm nodules were found on the lungs of lambs originating from the north or north-east of Iceland (Figure 4), which corresponds with the geographical distribution results of $M$. capillaris obtained with the faecal examination method (see Figure 5).

Larvae per gram values (lpg) of $M$. capillaris in lamb faeces markedly varied in the present study (Figure 5). The highest lpg values $(>100$, red dots) were reported from three lambs

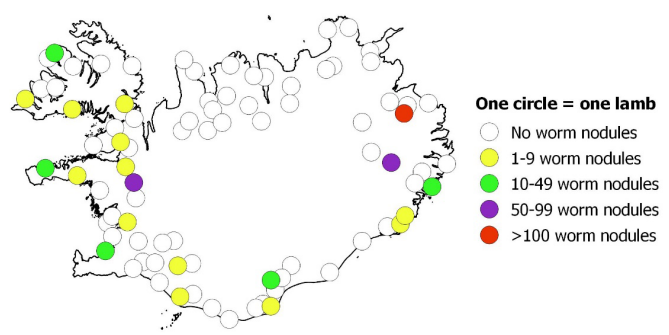

Figure 4. Worm nodule numbers caused by Muellerius capillaris detected on the lung surface of 84 lambs originating from different parts of Iceland in the autumn 1992 and 1993. Colours represent different worm nodule intensities (four categories); open circles denote that no nodules were observed.

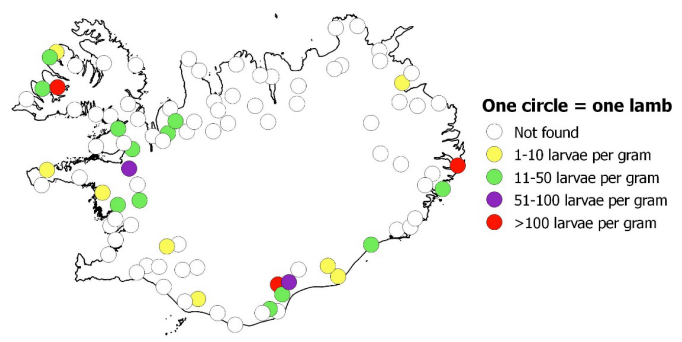

Figure 5. Larvae per gram (lpg) values of Muellerius capillaris first stage larvae (L1) detected in faeces of lambs during autumn in 1992 and 1993 on 94 sheep farms in different parts of Iceland. One faecal sample was examined from each farm. Empty circles indicate that no larvae were detected in the faeces; colours represent different intensities.

originating from the Westfjords, and south and east Iceland, respectively. Most often, however, infections were confirmed from the southern and the western part of the island. Only a single lamb (a yellow dot in Vopnafjörður) from a total of 27 farms located in mid-north and the north-eastern part of the country was found to be infected with a low number of $M$. capillaris larvae (Figure 5).

\section{Protostrongylus sp.}

Examinations of lungs revealed Protostrongylus sp. infection in two lambs from two adjacent farms located in the north of Iceland (Figure 6). Intensity of infection was low; a single worm was detected in each case. No larvae were detected by faecal examinations from these lambs. 


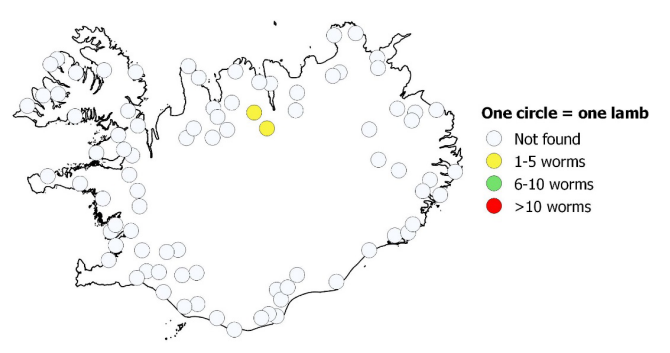

Figure 6. Intensity of infection and geographical distribution of adult Protostrongylus sp. specimens in lungs sampled during the slaughtering period in 1992 and 1993 from lambs on 84 sheep farms in different parts of Iceland. The species was not detected in faecal samples from 94 farms.

\section{Dictyocaulus filaria}

Marked differences were observed between the methods used to evaluate D. filaria infections in lambs in the survey (Figure 7). Adult worms were found in the trachea, bronchi, or bronchioles of lambs from 14 farms, on average three worms per lamb. The highest intensity detected (17 worms, Table 2) was found in a lamb from a farm located in East Iceland (Figure 7A). However, larvae in faecal samples were detected in only one lamb where no adults were found (Figure 7B). Thus, in total 15 lambs $(15.6 \%)$ were infected with D. filaria. Infected lambs were detected in all parts of the country but most often they were detected in the southern and western parts (Figure 7).

A

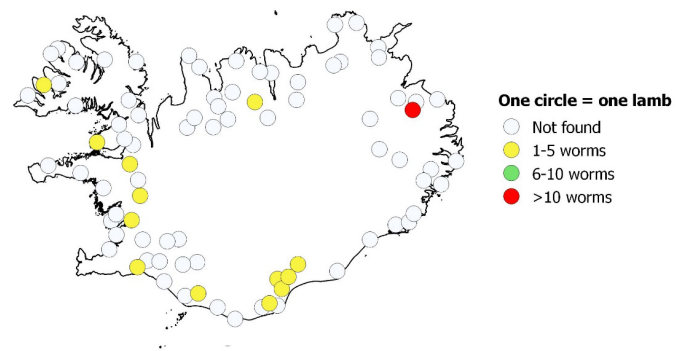

\section{DISCUSSION}

Muellerius capillaris

Magnús Einarsson (1904) reported findings of "premature wormlings" in great numbers in sheep lungs, without any visible presence of adult worms. There, he was regarded as reporting findings of first-stage $M$. capillaris larvae, but due to the adults being small and embedded in the lung tissue and thus hard to detect, they were not noticed. Three decades later another practicing veterinarian in Iceland, Ásgeir Einarsson (1936), proclaimed that $M$. capillaris was so common in Iceland in the 1930s that "a sheep being free from infection should be considered as an exception". Thus, by then, most sheep in the country were regarded as infected. In 1965, Gíslason reported finding lung lesions that he related to $M$. capillaris in $25 \%$ of inspected lambs $(\mathrm{n}=30)$, and Richter (1974) found M. capillaris larvae in faecal samples from four of eight lambs and in seven of eight adult sheep examined. Furthermore, Richter reported M. capillaris in both faecal and post-mortem examination of lambs in 1976, and in lambs and ewes in 1979. Both studies, however, reported low intensity. Lastly, Richter et al. (1983) reported a $M$. capillaris prevalence of $12.5 \%$ in lambs $(n=24)$, with the highest intensity counts being $19 \mathrm{lpg}$.

Worm nodules were present on $23.8 \%$ of examined lungs. They are a well-known indicator for Muellerius sp. or Cystocaulus sp. infections in lungs of ruminants (Mehlhorn

B

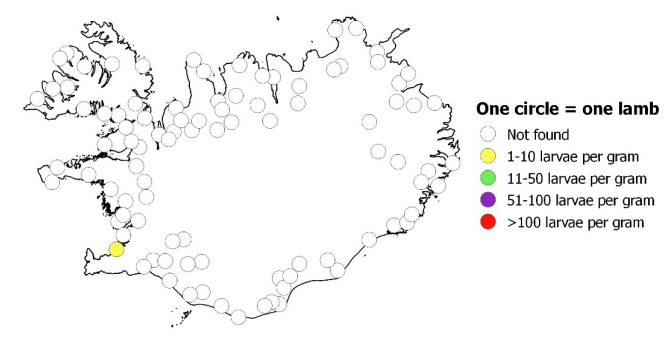

Figure 7. Geographical distribution and infection intensity of the lungworm nematode Dictyocaulus filaria in lambs in Iceland during autumn 1992 and 1993 based on direct search for adult and maturing nematodes in the lungs ( $\mathrm{n}=84)(7 \mathrm{~A})$ and the detection of first stage larvae in faecal samples $(\mathrm{n}=94)(7 \mathrm{~B})$. 
1988, Deplazes et al 2016). However, as Cystocaulus sp. has never been found in Iceland and was not recorded in faecal samples during this study, the presence of such worm nodules on the lung surface were taken as an indicator of an $M$. capillaris infection.

In the present study, representing findings from the early 1990s, larvae of M. capillaris were confirmed in $35.1 \%$ of the lambs, with an average intensity of $33 \mathrm{lpg}$. By then, this nematode was prevalent in most areas of Iceland except in the mid-northern and north-eastern parts of the country where only one farm was recorded with infection.

\section{Protostrongylus sp.}

Magnús Einarsson (1904) described finding a type of lungworm he called Strongylus paradoxus in lungs examined from the eastern and north-eastern parts of Iceland. This worm was reported being shorter than S. filaria and brownish in colour, which resembled descriptions of Protostrongylus sp. The following year Einarsson (1905) reported having found the smaller lungworm species (which he then now described as Strongylus communatus) in the lungs of $89.5 \%$ of lambs and in all lungs examined from adult sheep. We assume that this obviously very common lung nematode was indeed Protostrongylus sp. No further reports of Protostrongylus sp. in Iceland can be found in the literature, but Einarsson (1936) reported Protostrongylus rufescens in East Iceland while working as a veterinarian in that part of the country.

In the present study, no larvae of the genus Protostrongylus were found in faecal samples. Only two lambs, both originating from farms in north Iceland, were found to be infected with the adult stage. To clear the taxonomical identification the Protostrongylus sp. specimens obtained in the study are currently being sequenced and examined morphologically.

\section{Dictyocaulus filaria}

In 1904, Magnús Einarsson examined an outbreak of a respiratory illness that caused fatalities of sheep in east Iceland (Einarsson 1904). There he reported findings of Strongylus filaria (referring to D. filaria), and in a followup study he reported infection with this species in $47 \%$ of examined lambs and $56 \%$ of examined adults (Einarsson, 1905). Later, Ásgeir Einarsson (1936) stated that D. filaria was a common finding in Icelandic sheep. Gíslason (1965) found D. filaria in the lungs of $76.7 \%$ of dissected lambs $(n=30)$ from a farm in south-west Iceland in 1964, with an average intensity of 4.8 worms. Later, using the Baermann technique, Richter (1974) recovered D. filaria larvae from faeces in $50 \%$ of tested lambs $(n=8)$ and $12.5 \%$ of adults $(n=8)$, with an intensity of infection of five lpg for both age groups. Further, Richter (1976) reported finding D. filaria in a study performed in the western part of Iceland, both from faecal samples and post-mortem examinations of lambs.

In this study $D$. filaria was recovered from $16.7 \%$ of the lungs but larvae were only present in one faecal sample. The absence of larvae in faeces of lambs confirmed to have the nematode in their lungs could be explained by still maturing infections or the fact that the samples had been frozen for months before analysis. This prevalence is generally lower than that reported in previous decades. Our results also indicate that in the early 1990s $D$. filaria was found in all parts of Iceland, though more commonly reported in the south and west than in the northern and eastern part of the country.

Neighbouring countries

Compared with data from neighbouring countries, Iceland has a similar species composition of lungworms in sheep as reported from the Faroe Islands (Protostronglus, however, is missing) and Norway (Cystocaulus also occurs), whereas most lungworm species have been reported from the UK (Table 3 ). It is worth noting that $M$. capillaris is the only species that has been reported in all the neighbouring countries and D. filaria has been reported in all countries except Greenland. 
Table 3. Lungworm species reported from sheep in Iceland, the Faroe Islands, Greenland, Norway, and the United Kingdom.

\begin{tabular}{|c|c|c|c|c|c|}
\hline & $\mathrm{I}$ & $\mathrm{F}$ & $\mathrm{G}$ & $\mathrm{N}$ & UK \\
\hline \multicolumn{6}{|l|}{ Large lungworms } \\
\hline Dictyocaulus filaria & + & + & & + & + \\
\hline \multicolumn{6}{|l|}{ Small lungworms } \\
\hline Cystocaulus ocreatus & & & & + & + \\
\hline Muellerius capillaris & + & + & + & + & + \\
\hline Neostrongylus linearis & & & & & + \\
\hline Protostrongylus sp. & + & & & + & + \\
\hline
\end{tabular}

*References: Iceland (I): Present study. The Faroe Islands (F): Hanusson (2001). Greenland (G): Rose et al. (1984), Egill Steingrímsson - Chief veterinary officer, Nuuk, pers. comm. (2020). Norway (N): Gjerde (2011). United Kingdom (UK): Rose (1961), Thomas et al. (1970).

\section{Minimum values}

The lpg values presented in this study are considered to represent underestimates. Firstly, the faecal samples examined had been kept frozen at $-20^{\circ} \mathrm{C}$ for up to 16 months before examination. This could have resulted in incidents being overlooked, especially when infections were light and larvae mortality had occurred. Ideally, the Baermann technique should be performed on fresh faecal samples. Generally, however, first-stage parasitic larvae can withstand freezing temperatures of $-10^{\circ} \mathrm{C}$ and higher (Cabaret et al. 1991, Ferdushy \& Hasan 2010, Kafle et al. 2018), with a recorded survival rate of over $80 \%$ after three months (Kafle et al. 2018). First-stage larvae of $M$. capillaris can withstand low temperatures outside its host for longer than other protostrongylids (Reguera-Feo et al. 1986). M. capillaris larvae were reported by Rose (1957) to survive temperatures down to $-7.5^{\circ} \mathrm{C}$ for 12 days when water was used as a medium, but Cabaret (1992) reported survival of $52 \%$ of first-stage larvae when kept frozen at $-20^{\circ} \mathrm{C}$ in tap water for 7.5 months. According to a study by Rose (1955), larvae of $D$. filaria show an optimal survival rate at low temperatures, in fact up to 48 weeks.

Secondly, faecal examination of the 4-51/2 month old lambs from September and October were unable to detect lungworm infections in cases when still maturing female worms had not yet started laying eggs in the lungs and larvae therefore could not yet be detected in the faeces. The prepatent period for D. filaria is 26-30 days, and additionally it takes the larvae up to three weeks to reach the infective stage in the environment (Deplazes et al. 2016). Similarly, the prepatent period for Protostrongylus sp. lasts 5-6 weeks, and 6-10 weeks for M. capillaris (Taylor et al. 2007). Thus, especially in cases when lambs have recently been brought from the more or less infection-free mountain areas in late summer or early autumn to the lowland around the farms, where parasite infections can be acquired (Skirnisson 2011), maturing lungworm infections could not yet be detected with the Baermann method.

\section{Intermediate hosts}

The distribution and abundance of the snail intermediate hosts used for larvae development by protostrongylid nematodes in Iceland might influence their infection intensity and distribution within the country. Unfortunately, no research has so far been carried out on this subject in Iceland. Abroad, however, $M$. capillaris is reported to infect a variety of snails and slugs (Hobmaier \& Hobmaier, 1929, Hobmaier \& Hobmaier 1930a) of which the genera of Helix, Arianta, Cepaea, Succinea, Limax and Arion are also reported to occur in Iceland (Einarsson 1977, Ólafsson 2017). Protostrongylus sp., however, is more selective for an intermediate host than $M$. capillaris; for example, it is known to infects snails belonging to the genera Arianta and Theba (Hobmeier \& Hobmaier 1930b, Taylor et al. 2007), terrestrial snail genera that have been reported in Iceland (Einarsson 1977, Ólafsson 2017).

\section{CONCLUSION}

Studies performed in the early 1990 s to evaluate lung nematode infections of $4-51 / 2$ month old lambs of the Icelandic breed of sheep revealed three species, two protostrongylids, M. capillaris and Protostrongylus sp., and the dictyocaulid $D$. filaria. All had previously been reported from 
sheep in Iceland. M. capillaris was found in lambs from all parts of Iceland except from the mid-north and northeast areas; Protostrogylus sp. was exclusively detected on two adjacent farms in the north; D. filaria was mainly found on farms in the southern and western areas.

In the present study direct examinations of lungs were regarded as roughly reflecting infection prevalence, abundance, and geographical distribution of the large-sized species (Protostrongylus sp. and D. filaria). Faecal examinations, however, represented minimal values, partly due to known mortality of larvae in faeces that have been kept frozen for months prior to larvae counts with the Baermann method, but also due to the sampling time in September and October when maturing infections of recently infected lambs were still undetectable.

Further studies are needed to record the current prevalence and infection intensity of lung nematodes in Icelandic sheep. Additionally, research on the intermediate host range and their infections by protostrongylid nematodes in the country should be performed.

\section{ACKNOWLEDGEMENTS}

Sincere thanks to Sigurður H. Richter who gave us permission to work with his material and provided access to results of larvae counts performed by him and his co-workers at Keldur in the 1990s. A number of veterinarians are also thanked for collecting and sending the samples to Keldur. In 2019 the project was funded by The Agricultural Productivity Fund in Iceland.

\section{REFERENCES}

Act No. 25/1993 on animal diseases and measures to control them. Icelandic legislation - Edition no. $144 a$.

Belay M \& Mengsha M 2016. Prevalence and financial losses of lungworm infection in sheep in South Wollo Zone, Ethiopia. Journal of Animal Research 6(1), 53-58. https://doi.org/10.5958/2277-940X.2016.00010.3.

CabaretJ 1992. Long-term conservation of Muellerius capillaris (Nematoda, Protostrongylidae) firststage larvae: Cryopreservation versus storage at $-20^{\circ}$ C. Parasitology Research 78, 451-452.

Cabaret J, Risye Riseani S \& Baeza E 1991. Survival of sheep and goat first-stage protostrongylid larvae in experimental conditions: Influence of humidity and temperature. Journal of Helminthology 65, 201-207.

Deplazes P, Eckert J, Mathis A, Himmelstjerna GvS \& Zahner H 2016. Parasitology in Veterinary Medicine. Wageningen Academic Publishers, The Netherlands, $650 \mathrm{pp}$.

Einarsson Á 1936. Ormaveiki í sauðfé [Helminthiasis in sheep]. Freyr 31, 96-103. [In Icelandic].

Einarsson Á 1977. Íslenskir landkuðungar. [Terrestrial snail in Iceland]. Náttúrufrceðingurinn 47(2), 65-128.

Einarsson M 1904. Lungnadrep og skitupest [Lung necrosis and diarrhoea]. Freyr 1, 53-67. [In Icelandic].

Einarsson M 1905. Ormasýki í sauðfé [Helminthiasis in sheep]. Freyr 2, 1-3. [In Icelandic].

Ferdushy T \& Hasan MT 2010. Survival of firststage larvae (L1) of Angiostrongylus vasorum under various conditions of temperature and humidity. Parasitology Research 107, 1323-1327. https://doi.org/10.1007/s00436-010-2004-x.

Gasser RB, Chilton NB, Hoste H \& Beveridge I 1993. Rapid sequencing of rDNA from single worms and eggs of parasitic helminths. Nucleic Acids Research 21(10), 2525-2526. https://doi.org/10.1093/nar/21.10.2525.

Georgiev DM \& Georgiev BB 2002. Terrestrial gastropods as intermediate hosts of protostrongylid nematodes in pastures for sheep and goats in the region of Stara Zagora, Bulgaria. Acta Zoologia Bulgarica 54(3), 47-54.

Gerichter CB 1951. Studies on the lung nematodes of sheep and goats in the Levant. Parasitology 41, 166-183.

Gíslason G 1965. Ormar í sauðfé [Helminths of sheep]. Arbók landbúnaðarins 16, 87-109. [In Icelandic].

Gjerde B 2011. Parasittar hos sau - kompendium i veterinærmedisk parasittologi [Parasites in sheep - compendium in veterinary parasitology] 12 th ed. Oslo, 47 p. [In Norwegian].

Hanusson B 2001. Parasites in sheep in the Faroe Islands. Fróðskaparrit 48, 175-194. 
Henriksen SA 1965. En forbedret teknik ved undersøgelser for lungeormelarver $i$ faeces. [An improved technique for the examination of faeces for larvae of lungworms]. Nordisk Veterincermedicin 17, 446-454. [In Norwegian].

Hobmaier A \& Hobmaier M 1929. Über die Entwicklung des Lungenwurmes Synthetocaulus capillaris in Nacht-, Weg- und Schnirkelschnecken. [About the development of the lungworm Synthetocaulus capillaris in slugs and snails]. Berliner und Münchener tierärztliche Wochenschrift 80, 497-500. [In German].

Hobmaier A \& Hobmaier M 1930a. Limax und Succinea, zwei neue zwischenwirte von Muellerius (Synthetocaulus) capillaris des Schafes und der Ziege [Limax and Succinea, two new intermediate hosts of Muellerius (Synthetocaulus) capillaris in sheep and goats]. Berliner und Münchener tierärztliche Wochenschrift $81 ， 285-287$. [In German].

Hobmaier A \& Hobmaier M 1930b. Life history of Protostrongylus (Synthetocaulus) rufescens. Proceedings of the Society for Experimental Biology and Medicine 28, 156-158.

Jenkins EJ, Veitch AM, Kutz SJ, Hoberg EP \& Polley L 2006. Climate change and the epidemiology of protostrongylid nematodes in northern ecosystems: Parelaphostrongylus odocoilei and Protostrongylus stilesi in Dall's sheep (Ovis d. dalli). Parasitology 132(3), 387-401.

https://doi.org/10.1017/S0031182005009145.

Kafle P, Peacock SJ, Grond S, Orsel K \& Kutz S 2018. Temperature-dependent development and freezing survival of protostrongylid nematodes of Arctic ungulates: Implications for transmission. Parasites \& Vectors 11(1), 1-12. https://doi.org/10.1186/s13071-018-2946-x.

Mehlhorn H (ed.) 1988. Parasitology in focus - facts and trends. Springer-Verlag, Germany, 924 pp.

Ministry of Agriculture, Fisheries and Food 1986. Manual of Veterinary Parasitological Laboratory Techniques. H.M. Stationery Office, London, 160 pp.

Ólafsson E 2017. Lungnasniglar (Pulmonata). Accessed 13.11.2020 at https://www.ni.is/biota/ animalia/mollusca/gastropoda/pulmonata.

Pandey VS, Cabaret J \& Fikri A 1984. The effect of strategic anthelmintic treatment on the breeding performance and survival of ewes naturally infected with gastrointestinal strongyles and protostrongylids. Annals of Veterinary Research 15(4), 491-496.

Reguera-Feo A, Rojo-Vazquez FA \& Cordero-DelCampillo M 1986. On first-stage larval resistance under controlled conditions of three species of nematodes of the family protostrongylidae, Leiper, 1926. Annales de Parasitologie Humaine et Compurée 16, 297-301.

Richter SH 1974. Sheep parasites in Iceland. Journal of Agricultural Research in Iceland 6, 3-22.

Richter SH 1976. Parasites in sheep and cattle in Iceland. A preliminary report on the UNDP/FAO ICE 73/003 project. Field season 1976. Keldur, Reykjavík, 37 pp.

Richter SH 1979. Parasites in sheep and cattle in Iceland. A preliminary report on a study of parasites in sheep and cattle grazing on intensively managed pastures at Hvanneyri, Iceland. Field season 1978 and 1979. Keldur, Reykjavík, 44 pp.

Richter SH 2002. Gastrointestinal helminths in sheep (Ovis aries) in Iceland; their prevalence, abundance, and geographic distribution. Icelandic Agricultural Sciences 15, 111-128.

Richter SH, Eydal M \& Símonarson B 1983. Sníkjudýr og haustbeit lamba á há [Parasites and field grazing of lambs in autumn]. Journal of Agricultural Research in Iceland 15, 29-40. [In Icelandic].

Robb LA \& Samuel WM 1990. Gastropod intermediate hosts of lungworms (Nemotoda: Protostrongylidae) on a bighorn sheep winter range: Aspects of transmission. Canadian Journal of Zoology 68(9), 1976-1982.

Rose JH 1955. Observations on the bionomics of the free-living larvae of the lungworm Dictyocaulus filaria. Journal of Comparative Pathology and Therapeutics 65(4), 370-381.

Rose JH 1957. Observations on the bionomics of the free-living first stage larvae of the sheep lungworm Muellerius capillaris. Journal of Helminthology 31, 17-28.

Rose JH 1961. Three lungworms recently recorded from British sheep. Research in Veterinary Science 2(3), 253-258.

Rose CH, Jacobs DE, Jorgensen RJ \& Nansen P 1984. Studies of helminth parasites of sheep in Southern Greenland. Nordisk Veterinaermedicin 36(3-4), 77-78. 
Sigurðsson B 1954. Paratuberculosis (Johne's disease) of sheep in Iceland. The British Veterinary Journal 110, 307-322.

Skirnisson K 2011. Association of farming practice and the seasonal occurrence of gastrointestinal helminths in a flock of sheep in Iceland. Icelandic Agricultural Sciences 24, 43-54.

Soulsby EJL 1965. Textbook of Veterinary Clinical Parasitology: Vol. I - Helminths. Blackwell Scientific Publications, Oxford, 1120 pp.
Statistics Iceland 2020. Production - Statistics Iceland. Accessed 08.04.2020 at https://statice.is/ statistics/business-sectors/agriculture/production/

Taylor MA, Coop RL \& Wall RL 2007. Veterinary parasitology, 4th ed. Blackwell Publishing, Oxford, $1006 \mathrm{pp}$.

Thomas RJ, Nunns VJ \& Boag B 1970. The incidence of lungworm infection in sheep in NorthEast England. Veterinary Record 87(3), 70-75.

Manuscript received 22.1.2021 Accepted 3.5.2021 